\title{
STUDY OF THE EFFECTS OF ADJUVANTS ASSOCIATED WITH INSECTICIDES ON THE PHYSICOCHEMICAL PROPERTIES OF THE SPRAY SOLUTION AND CHARACTERIZATION OF DEPOSITS ON WHEAT AND MAIZE LEAVES UNDER SIMULATED RAIN
}

\author{
Adriano A. Melo ${ }^{*}$, Mauricio Hunsche ${ }^{2}$, Jerson V. C. Guedes ${ }^{3}$, Lucas Hahn³, Natalie M. Feltrin ${ }^{3}$
}

${ }^{1 *}$ Corresponding author. Federal University of Santa Maria/ Santa Maria - RS, Brazil.

E-mail: adrianoarrue@hotmail.com | ORCID ID: https://orcid.org/0000-0001-6868-4347

\section{KEYWORDS}

surface tension, contact angle, potential of hydrogen $(\mathrm{pH})$, coverage, and deposit.

\begin{abstract}
The association of adjuvants with phytosanitary products has been tested for several years but is commonly recommended without considering technical and scientific criteria. This study aimed to evaluate the influence of the association of insecticides with different adjuvants on surface tension, contact angle, coverage, hydrogen ionic potential $(\mathrm{pH})$, and the formation of deposits exposed to rain. The insecticides thiamethoxam, imidacloprid, and lambda-cyhalothrin were tested at doses of $75 \mathrm{~g} \mathrm{ha}^{-1}, 150 \mathrm{~g} \mathrm{ha}^{-1}$, and $150 \mathrm{~g} \mathrm{ha}^{-1}$, respectively, with a spray volume of $200 \mathrm{~L} \mathrm{ha}^{-1}$. Break-Thru $240^{\circledR}$, Break-Thru $233^{\circledR}$, BreakThru Union ${ }^{\circledR}$, Oleo FC Agraröl ${ }^{\circledR}$, and Naturo'il ${ }^{\circledR}$ were added to each of these spray solutions. The results showed that the addition of adjuvants reduced the surface tension and contact angle, and consequently, increased droplet coverage. No deposit pattern was found in the thiamethoxam, imidacloprid, and lambda-cyhalothrin insecticides associated with the adjuvants and a higher amount of residue was observed on wheat leaves than on maize leaves. The use of adjuvants can be an alternative to improve the efficiency of insecticides, allowing the product to achieve its full control potential.
\end{abstract}

\section{INTRODUCTION}

The addition of adjuvants to the spray solution interferes with the application of phytosanitary products, modifying certain properties of the spray solution and/or increasing its biological efficiency. The adjuvants can alter the physicochemical properties of the spray solution, thus altering factors such as wettability, adhesion, and spreading of spray droplets and contributing to better retention and penetration of the active ingredient (Azevedo \& Castelani, 2013). However, this improvement has not been observed for all adjuvants; it depends on the product used and the biological target (Melo et al., 2014).

Surface tension is a physical phenomenon that occurs on the surface of water droplets. In agricultural applications where water is the main vehicle, this is the result of the attraction of hydrogen molecules. These cohesive forces tend to reduce the surface area occupied by the liquid, thus causing the formation of spherical drops. This shape decreases the contact between the droplet and the leaf surface, resulting in an increased contact angle between the leaf and the product, reducing its penetration rate (Hazen, 2000).
The use of adjuvants can reduce the surface tension of insecticide spray solutions (Costa et al., 2017). This effect improves droplet coverage. However, this response varies according to the characteristics of the adjuvant used (Holloway et al., 2000). The $\mathrm{pH}$ of the spray solution is another physicochemical characteristic that can be influenced by the addition of adjuvants (Cunha et al. 2017).

Rain, which is one the environmental factors that cause a reduction in the efficiency of phytosanitary products, has an immediate effect on the products on the leaf surface. The influence of rain on the efficiency of crop protection agents is related to the tenacity of the deposits (Hunsche et al., 2011). Some adjuvants contribute to reducing the effect of rain after spraying (rainfastness), i.e., they reduce the minimum period necessary without rain, so that the action of phytosanitary products is not compromised (Melo et al., 2015).

The aim of the present study was to evaluate the influence of the association of insecticides with different adjuvants on surface tension, contact angle, coverage, potential of hydrogen $(\mathrm{pH})$, and the formation of deposits on wheat and maize plants exposed to rain.

\footnotetext{
${ }^{2}$ COMPO EXPERT GmbH, Münster/ Germany.

${ }^{3}$ Federal University of Santa Maria/ Santa Maria - RS, Brazil.

Received in: 2-21-2018

Accepted in: 2-22-2019
} 


\section{MATERIAL AND METHODS}

The experiments were conducted at the Institute of Crop Science and Resource Conservation at the University of Bonn, Bonn, Germany. The treatments comprised the association of insecticides (Factor A) and adjuvants (Factor D). Tests were performed on the solutions to determine factors including their surface tension, contact angle, and $\mathrm{pH}$. After spraying, additional tests were performed, including tests to assess droplet coverage, and images of the deposits were taken with a scanning electron microscope to evaluate the effect of rain on the treatments.

Wheat (Triticum aestivum 'Oakley') and maize (Zea mays 'Lorena') plants were sown in pots (TEKUContainer EC 17, volume $=2 \mathrm{~L}$, Pöppelmann $\mathrm{GmbH} \&$ Co. KG, Lohne, Germany) with a substrate prepared from peat and sand ( 5 plants for wheat and 1 for maize). Each pot was an experimental unit (EU) and was cultivated indoors. Each treatment consisted of 10 EUs, totaling 180 EUs, which were kept in a controlled environment under a temperature of $20 \pm 5^{\circ} \mathrm{C}$ and relative air humidity of $50 \pm$ $10 \%$. The plants received fertigation with a standard commercial fertilizer, according to the needs of each crop, during the entire period that they remained in the greenhouse. They were kept until they reached approximately $0.15 \mathrm{~m}$ in height, which was considered the ideal size for use in trials.

To determine the adjuvant doses, preliminary tests for surface tension and contact angle of adjuvants were performed with only water at different concentrations. The adjuvants and doses tested were: Break-Thru ${ }^{\circledR}$ S240, Break-Thru $^{\circledR}$ S233, Break-Thru ${ }^{\circledR}$ Union (Evonik Goldschmidt GmbH, Essen, Germany), Oleo FC Agraröl ${ }^{\circledR}$, and Naturo'il ${ }^{\circledR}$ (Stoller Chemical Co, Houston, USA). Three different concentrations $(0.01 \%, 0.05 \%$, and $0.1 \%$ of the spray volume) were tested for Break-Thru ${ }^{\circledR}$ adjuvants, whereas four concentrations $(0.1 \%, 0.5 \%, 1 \%$, and $2 \%$ of the spray volume) were tested for Oleo FC Agraröl $^{\circledR}$ and Naturo'il ${ }^{\circledR}$.

Surface tension was determined using the pendant drop method (10 drops per treatment solution) and the contact angle was measured using the sessile drop method (3 $\mu \mathrm{L} ; \mathrm{n}=10$ ). A DSA $30 \mathrm{E}$ goniometer (Krüss $\mathrm{GmbH}$, Hamburg, Germany) was used for evaluation of both wheat and maize leaves. The wheat and maize leaves were cut in half and fixed on slides using double-sided tape, and drops were applied to the central area of the leaf, avoiding the central vein.

Based on preliminary studies (Table 2), adjuvant doses were defined for other studies. The same methodology was used to evaluate the surface tension and contact angle of the treatments, and the insecticides evaluated were: thiamethoxam (Actara $25 \mathrm{WG}^{\circledR}$, Syngenta, Basel, Switzerland) imidacloprid (Confidor ${ }^{\circledR}$, Bayer, Leverkusen, Germany) and lambda-cyhalothrin (Karate ${ }^{\circledR}$, Syngenta, Basel, Switzerland), with simulated applications with a spray volume of $200 \mathrm{~L} \mathrm{ha}^{-1}$. The treatments are described in Table 1.

TABLE 1. Insecticides, adjuvants, and their doses used in tests on wheat and maize.

\begin{tabular}{|c|c|c|c|}
\hline $\begin{array}{c}\text { Insecticides } \\
\text { (Factor A) }\end{array}$ & $\begin{array}{c}\text { Dose } \\
\text { (g of i.a. ha) }\end{array}$ & $\begin{array}{l}\text { Adjuvants } \\
\text { (Factor D) }\end{array}$ & $\begin{array}{l}\text { Dose } \\
(\mathrm{v} / \mathrm{v})\end{array}$ \\
\hline $\begin{array}{l}\text { 1. Thiamethoxam } \\
\text { 2. Imidacloprid } \\
\text { 3. Lambda-cyhalothrin }\end{array}$ & $\begin{array}{c}75 \\
150 \\
150\end{array}$ & $\begin{array}{ll}\text { 1. } & \text { Water } \\
\text { 2. } & \text { Break Thru }{ }^{\circledR} \mathrm{S} 240 \\
\text { 3. } & \text { Break Thru }{ }^{\circledR} \mathrm{S} 233 \\
\text { 4. } & \text { Break Thru }{ }^{\circledR} \text { Union } \\
\text { 5. } & \text { FC Agraröl }{ }^{\circledR} \\
\text { 6. } & \text { Naturo'il }^{\circledR}\end{array}$ & $\begin{array}{l}\quad- \\
0.05 \% \\
0.05 \% \\
0.05 \% \\
0.5 \% \\
0.5 \%\end{array}$ \\
\hline
\end{tabular}

The $\mathrm{pH}$ was measured with a Hanna HI 223 benchtop $\mathrm{pH}$ meter, and all spray solutions and the water alone were measured. Four measurements were completed for each solution.

The Assistat $^{\circledR}$ statistical package was used to compare the results of surface tension and contact angle. The tables and graphs were generated in Excel $2013^{\circledR}$. The means were compared using Tukey's test ( $p$-value $=0.05)$.

The quality of the application was evaluated through the droplet coverage of the treatments, using a mechanized sprayer from the University of Bonn (B-PSA1; Department of Agricultural Engineering, University of Bonn, Germany), equipped with flat-fan nozzles (XR 110.03, Teejet, Illinois, USA) with a travel speed of $6 \mathrm{~km}$ $\mathrm{h}^{-1}$, operating with $300 \mathrm{kPa}$ pressure, and calibrated for a spray volume of $200 \mathrm{~L} / \mathrm{ha}$. Coverage was evaluated using hydrosensitive cards (Novartis AG, Basel, Switzerland) measuring $5 \mathrm{~cm}^{2}$, with four repetitions per treatment. The images of the cards were scanned and analyzed using Gotas $^{\circledR}$ software.
To evaluate the effect of rain on the deposits, $2 \mathrm{~h}$ after the plants were subjected to treatment, they were exposed to a rain intensity of $5 \mathrm{~mm} \mathrm{~h}^{-1}$ using a rain simulator (B-LRS-2 Department of Agriculture Engineering, University of Bonn, Germany). The plants were taken to the greenhouse for drying for $24 \mathrm{~h}$; plants not exposed to rain were used to compare the images of the deposits. Images were obtained using a scanning electron microscope (ESEM XL 30 FEI; Philips, Eindhoven, Holland), and the most representative images of the deposits were documented after the rain simulation.

\section{RESULTS AND DISCUSSION}

Preliminary tests showed that the addition of adjuvants altered the physicochemical properties of the spray volume (Table 2). The most appropriate doses of the Break-Thru ${ }^{\circledR}$ S240, Break-Thru ${ }^{\circledR}$ S233, and Break-Thru ${ }^{\circledR}$ Union organosilicone adjuvants were $0.05 \%(\mathrm{v} / \mathrm{v})$ and $0.5 \%(\mathrm{v} / \mathrm{v})$ for the Oleo FC Agraröl ${ }^{\circledR}$ and Naturo'il ${ }^{\circledR}$ oils, respectively. Thus, these doses were used in all trials. 
TABLE 2. Surface tension and contact angle for wheat and maize.

\begin{tabular}{|c|c|c|c|c|}
\hline \multirow{2}{*}{ Treatments } & \multirow{2}{*}{$\begin{array}{l}\text { Dose } \\
(\mathrm{v} / \mathrm{v})\end{array}$} & \multirow{2}{*}{$\begin{array}{l}\text { Surface tension } \\
\qquad\left(\mathrm{mN} \mathrm{m}^{-1}\right)\end{array}$} & \multicolumn{2}{|c|}{ Contact angle $\left(^{\circ}\right)$} \\
\hline & & & Wheat & Maize \\
\hline $\begin{array}{l}\text { 1. Water } \\
\text { 2. Water }+ \text { Break-Thru }{ }^{\circledR} \text { S233 } \\
\text { 3. Water }+ \text { Break-Thru }{ }^{\circledR} \text { S233 } \\
\text { 4. Water }+ \text { Break-Thru }{ }^{\circledR} \text { S233 } \\
\text { CV\% }\end{array}$ & $\begin{array}{c}- \\
0.01 \% \\
0.05 \% \\
0.10 \%\end{array}$ & $\begin{array}{l}72.7 \mathrm{a} \\
69.2 \mathrm{~b} \\
34.2 \mathrm{c} \\
24.6 \mathrm{~d} \\
2.4\end{array}$ & $\begin{array}{c}124.3 \mathrm{a} \\
109.2 \mathrm{~b} \\
94.3 \mathrm{c} \\
68.6 \mathrm{~d} \\
7.0 \\
\end{array}$ & $\begin{array}{c}110.4 \mathrm{a} \\
109.5 \mathrm{~b} \\
93.1 \mathrm{c} \\
65.1 \mathrm{~d} \\
7.7 \\
\end{array}$ \\
\hline \multirow{2}{*}{ Treatments } & \multirow{2}{*}{$\begin{array}{l}\text { Dose } \\
(\mathrm{v} / \mathrm{v})\end{array}$} & \multirow{2}{*}{$\begin{array}{l}\text { Surface tension } \\
\qquad(\mathrm{mN} \mathrm{m}-1)\end{array}$} & \multicolumn{2}{|c|}{ Contact angle $\left({ }^{\circ}\right)$} \\
\hline & & & Wheat & Maize \\
\hline $\begin{array}{l}\text { 1. Water } \\
\text { 2. Water }+ \text { Break-Thru }{ }^{\circledR} \text { S240 } \\
\text { 3. Water }+ \text { Break-Thru }{ }^{\circledR} \text { S240 } \\
\text { 4. Water + Break-Thru }{ }^{\circledR} \text { S240 } \\
\text { CV\% }\end{array}$ & $\begin{array}{c}- \\
0.01 \% \\
0.05 \% \\
0.10 \%\end{array}$ & $\begin{array}{l}72.8 \mathrm{a} \\
31.1 \mathrm{~b} \\
22.8 \mathrm{c} \\
21.8 \mathrm{c} \\
2.8 \\
\end{array}$ & $\begin{array}{l}119.3 \mathrm{a} \\
91.4 \mathrm{~b} \\
54.7 \mathrm{c} \\
39.3 \mathrm{~d} \\
8.4 \\
\end{array}$ & $\begin{array}{l}105.7 \mathrm{a} \\
85.2 \mathrm{~b} \\
52.2 \mathrm{c} \\
33.6 \mathrm{~d} \\
7.5 \\
\end{array}$ \\
\hline \multirow{2}{*}{ Treatments } & \multirow{2}{*}{$\begin{array}{l}\text { Dose } \\
(\mathrm{v} / \mathrm{v})\end{array}$} & \multirow{2}{*}{$\begin{array}{l}\text { Surface tension } \\
\quad\left(\mathrm{mN} \mathrm{m}^{-1}\right)\end{array}$} & \multicolumn{2}{|c|}{ Contact angle $\left(^{\circ}\right)$} \\
\hline & & & Wheat & Maize \\
\hline $\begin{array}{l}\text { 1. Water } \\
\text { 2. Water }+ \text { Break-Thru }{ }^{\circledR} \text { Union } \\
\text { 3. Water }+ \text { Break-Thru }{ }^{\circledR} \text { Union } \\
\text { 4. Water }+ \text { Break-Thru }{ }^{\circledR} \text { Union } \\
\text { CV\% }\end{array}$ & $\begin{array}{c}- \\
0.01 \% \\
0.05 \% \\
0.10 \%\end{array}$ & $\begin{array}{l}72.7 \mathrm{a} \\
41.4 \mathrm{~b} \\
26.3 \mathrm{c} \\
23.9 \mathrm{~d} \\
2.8 \\
\end{array}$ & $\begin{array}{l}116.6 \mathrm{a} \\
97.4 \mathrm{~b} \\
69.2 \mathrm{c} \\
41.8 \mathrm{~d} \\
8.9 \\
\end{array}$ & $\begin{array}{c}110.9 \mathrm{a} \\
93.3 \mathrm{~b} \\
64.8 \mathrm{c} \\
42.9 \mathrm{~d} \\
6.3 \\
\end{array}$ \\
\hline \multirow{2}{*}{ Treatments } & \multirow{2}{*}{$\begin{array}{l}\text { Dose } \\
(\mathrm{v} / \mathrm{v})\end{array}$} & \multirow{2}{*}{$\begin{array}{l}\text { Surface tension } \\
\qquad\left(\mathrm{mN} \mathrm{m}^{-1}\right)\end{array}$} & \multicolumn{2}{|c|}{ Contact angle $\left(^{\circ}\right)$} \\
\hline & & & Wheat & Maize \\
\hline $\begin{array}{l}\text { 1. Water } \\
\text { 2. Water + Naturo'il }{ }^{\circledR} \\
\text { 3. Water + Naturo'il } \\
\text { 4. Water + Naturo'il }{ }^{\circledR} \\
\text { 5. Water + Naturo'il }{ }^{\circledR}\end{array}$ & $\begin{array}{l}- \\
0.10 \% \\
0.50 \% \\
1.00 \% \\
2.00 \%\end{array}$ & $\begin{array}{l}72.9 \mathrm{a} \\
68.7 \mathrm{~b} \\
38.7 \mathrm{c} \\
34.6 \mathrm{~d} \\
32.1 \mathrm{e} \\
2.2 \\
\end{array}$ & $\begin{array}{l}118.1 \mathrm{a} \\
99.9 \mathrm{~b} \\
96.9 \mathrm{~b} \\
84.8 \mathrm{c} \\
72.0 \mathrm{~d} \\
10.5\end{array}$ & $\begin{array}{l}107.2 \mathrm{a} \\
105.8 \mathrm{a} \\
85.4 \mathrm{~b} \\
77.9 \mathrm{~b} \\
68.9 \mathrm{c} \\
7.6 \\
\end{array}$ \\
\hline \multirow{2}{*}{ Treatments } & \multirow{2}{*}{$\begin{array}{l}\text { Dose } \\
(\mathrm{v} / \mathrm{v})\end{array}$} & \multirow{2}{*}{$\begin{array}{l}\text { Surface tension } \\
\quad\left(\mathrm{mN} \mathrm{m}^{-1}\right)\end{array}$} & \multicolumn{2}{|c|}{ Contact angle $\left({ }^{\circ}\right)$} \\
\hline & & & Wheat & Maize \\
\hline $\begin{array}{l}\text { 1. Water } \\
\text { 2. Water + Oil FC Agraröl }{ }^{\circledR} \\
\text { 3. Water + Oil FC Agraröl }{ }^{\circledR} \\
\text { 4. Water + Oil FC Agraröl }{ }^{\circledR} \\
\text { 5. Water + Oil FC Agraröl }{ }^{\circledR} \\
\qquad \mathrm{CV} \% \\
\end{array}$ & $\begin{array}{l}- \\
0.10 \% \\
0.50 \% \\
1.00 \% \\
2.00 \% \\
\end{array}$ & $\begin{array}{c}72.1 \mathrm{a} \\
72.2 \mathrm{a} \\
71.5 \mathrm{ab} \\
69.9 \mathrm{~b} \\
68.2 \mathrm{c} \\
1.9 \\
\end{array}$ & $\begin{array}{c}109.2 \mathrm{~b} \\
120.1 \mathrm{a} \\
121.6 \mathrm{a} \\
103.5 \mathrm{~b} \\
101.9 \mathrm{~b} \\
6.5 \\
\end{array}$ & $\begin{array}{c}119.6 \mathrm{a} \\
100.5 \mathrm{~b} \\
100.3 \mathrm{~b} \\
94.2 \mathrm{~b} \\
95.1 \mathrm{~b} \\
6.9 \\
\end{array}$ \\
\hline
\end{tabular}

*Values with the same letter in a column were not significantly different according to Tukey's test at 5\% probability level.

The association of adjuvants with insecticides resulted in reduced surface tension in all treatments (Table 3). However, although all adjuvants have decreased surface tension, the treatment with Oleo FC Agrarö ${ }^{\circledR}$ showed values very close to those for pure insecticide and pure water. The spray solutions containing organosilicone adjuvants (Break-Thru ${ }^{\circledR}$ S240 and Break-Thru ${ }^{\circledR}$ S233) were those with the lowest surface tension values. The use of organosilicone adjuvants to reduce surface tension has been previously reported (Wang \& Liu, 2007), although not for solutions associated with these insecticides and adjuvants, which are widely used in Brazilian agriculture. Furthermore, treatment with Naturo'il ${ }^{\circledR}$ had reduced surface tension at levels similar to those of treatments with organosilicone adjuvants. 
TABLE 3. Surface tension and contact angle when different insecticides and adjuvants are used on wheat and maize.

\begin{tabular}{|c|c|c|c|}
\hline \multirow{2}{*}{ Treatments } & \multirow{2}{*}{$\begin{array}{l}\text { Surface tension } \\
\qquad\left(\mathrm{mN} \mathrm{m}^{-1}\right)\end{array}$} & \multicolumn{2}{|c|}{ Contact angle $\left(^{\circ}\right)$} \\
\hline & & Wheat & Maize \\
\hline 1. Thiamethoxam & $73.1 \mathrm{a}$ & $122.5 \mathrm{a}$ & $111.7 \mathrm{a}$ \\
\hline 2. Thiamethoxam + Break-Thru ${ }^{\circledR} \mathrm{S} 240$ & $23.2 \mathrm{f}$ & $43.5 \mathrm{~d}$ & $34.9 \mathrm{e}$ \\
\hline 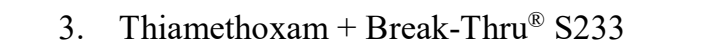 & $26.2 \mathrm{e}$ & $56.5 \mathrm{c}$ & $49.0 \mathrm{~d}$ \\
\hline 4. Thiamethoxam + Break-Thru ${ }^{\circledR}$ Union & $33.4 \mathrm{~d}$ & $95.3 \mathrm{~b}$ & $88.4 \mathrm{c}$ \\
\hline 5. Thiamethoxam + Oil FC Agraröl ${ }^{\circledR}$ & $68.6 \mathrm{~b}$ & $118.8 \mathrm{a}$ & $103.0 \mathrm{~b}$ \\
\hline 6. Thiamethoxam + Naturo'il ${ }^{\circledR}$ & $43.4 \mathrm{c}$ & $93.1 \mathrm{~b}$ & $88.0 \mathrm{c}$ \\
\hline 7. Water & $73.8 \mathrm{a}$ & $117.8 \mathrm{a}$ & $111.3 \mathrm{a}$ \\
\hline $\mathrm{CV} \%$ & 2.4 & 4.7 & 6.7 \\
\hline \multirow{2}{*}{ Treatments } & \multirow{2}{*}{$\begin{array}{l}\text { Surface tension } \\
\qquad\left(\mathrm{mN} \mathrm{m}^{-1}\right)\end{array}$} & \multicolumn{2}{|c|}{ Contact angle $\left({ }^{\circ}\right)$} \\
\hline & & Wheat & Maize \\
\hline 1. Imidacloprid & $71.7 \mathrm{ab}$ & $111.8 \mathrm{~b}$ & $110.9 \mathrm{a}$ \\
\hline 2. Imidacloprid + Break-Thru ${ }^{\circledR} \mathrm{S} 240$ & $22.2 \mathrm{e}$ & $46.3 \mathrm{f}$ & $38.6 \mathrm{~d}$ \\
\hline 3. Imidacloprid + Break-Thru ${ }^{\circledR} \mathrm{S} 233$ & $24.2 \mathrm{~d}$ & $56.1 \mathrm{e}$ & $53.5 \mathrm{c}$ \\
\hline 4. Imidacloprid + Break-Thru ${ }^{\circledR}$ Union & $35.7 \mathrm{c}$ & $95.1 \mathrm{c}$ & $89.6 \mathrm{~b}$ \\
\hline 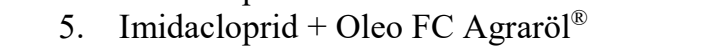 & $70.5 \mathrm{~b}$ & $113.4 \mathrm{ab}$ & $106.6 \mathrm{a}$ \\
\hline 6. Imidacloprid + Naturo'il ${ }^{\circledR}$ & $37.2 \mathrm{c}$ & $86.0 \mathrm{~d}$ & $82.5 \mathrm{~b}$ \\
\hline 7. Water & $73.1 \mathrm{a}$ & $120.2 \mathrm{a}$ & $108.0 \mathrm{a}$ \\
\hline \multirow{3}{*}{ Treatments } & 2.7 & 5.9 & 8.1 \\
\hline & Surface tension & \multicolumn{2}{|c|}{ Contact angle $\left({ }^{\circ}\right)$} \\
\hline & $\left(\mathrm{mN} \mathrm{m}^{-1}\right)$ & Wheat & Maize \\
\hline 1. Lambda-cyhalothrin & $70.8 \mathrm{~b}$ & $116.4 \mathrm{a}$ & $96.4 \mathrm{bc}$ \\
\hline 2. Lambda-cyhalothrin + Break-Thru ${ }^{\circledR} \mathrm{S} 240$ & $22.4 \mathrm{f}$ & $51.3 \mathrm{~d}$ & $43.4 \mathrm{f}$ \\
\hline 3. Lambda-cyhalothrin + Break-Thru ${ }^{\circledR} \mathrm{S} 233$ & $25.2 \mathrm{e}$ & $60.9 \mathrm{~d}$ & $53.6 \mathrm{e}$ \\
\hline 4. Lambda-cyhalothrin + Break-Thru ${ }^{\circledR}$ Union & $33.5 \mathrm{~d}$ & $101.2 \mathrm{~b}$ & $94.3 \mathrm{c}$ \\
\hline 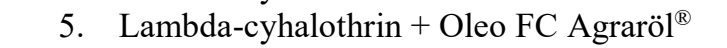 & $63.4 \mathrm{c}$ & $104.5 \mathrm{~b}$ & $102.2 \mathrm{ab}$ \\
\hline 6. Lambda-cyhalothrin + Naturo'il ${ }^{\circledR}$ & $32.7 \mathrm{~d}$ & $84.2 \mathrm{c}$ & $77.6 \mathrm{~d}$ \\
\hline 7. Water & $72.9 \mathrm{a}$ & $116.0 \mathrm{a}$ & $107.7 \mathrm{a}$ \\
\hline $\mathrm{CV} \%$ & 3.3 & 8.1 & 6.6 \\
\hline
\end{tabular}

* Values followed by the same letter in a column were not significantly different according to Tukey's test at $5 \%$ probability level.

The results of contact angle in the treatment using only water showed that the wheat $\left(\cong 117^{\circ}\right)$ and maize $(\cong$ $108^{\circ}$ ) leaves are hydrophobic, i.e., have contact angles greater than $90^{\circ}$ (Yuan \& Lee, 2013). Thus, the leaves of these two plants have poor wettability, confirming the importance of using adjuvants to improve this important attribute of spray droplets. The use of adjuvants proved to be an alternative for reducing the contact angle between the drop and the surface of the wheat and maize leaves. The treatment with Oleo FC Agrarö $l^{\circledR}$ was the only in which these values did not decrease, with similar results to those for insecticide spraying and water spraying in most cases. The association of Break-Thru ${ }^{\circledR}$ S240 and BreakThru $^{\circledR}$ S233 adjuvants with the three tested insecticides resulted in the lowest contact angle values, which allows for better wettability and spreading (Hess \& Foy, 2000). Thus, it is possible to state that the reduction of surface tension and consequently of the contact angle, after the addition of adjuvants, substantially improves the wettability, and consequently, the spray quality.
Despite the different modes of contamination by the target insects, a higher wettability is a desirable factor to improve the efficiency of the tested insecticides, thus enabling better control of pest insects. Although the Break$\mathrm{Thru}^{\circledR}$ Union adjuvant reduced surface tension to levels similar to the Break-Thru ${ }^{\circledR}$ S240 and Break-Thru ${ }^{\circledR}$ S233 adjuvants, it did not exhibit similar behavior to these products when the contact angle was assessed. This may be caused by its chemical composition; it should therefore not be recommended as a spreader. Although the Naturo'il ${ }^{\circledR}$ adjuvant is a vegetable oil in its basic composition, it already showed signals of reduction in surface tension at a dose of $0.50 \%$. These results differ from the findings of Castro et al. (2018) who reported that Naturo'il $l^{\circledR}$ required doses higher than $1 \%$ to reduce surface tension. This ability to reduce surface tension results in a lower contact angle, which shows that the product can improve wettability in wheat and maize leaves.

There was no significant change in the $\mathrm{pH}$ of the spray solution in the treatments tested (Table 4). This fact indicates that they can be used in the field without affecting the efficiency of insecticides. 
TABLE 4. Droplet coverage and $\mathrm{pH}$ with different insecticides and adjuvants.

\begin{tabular}{|c|c|c|}
\hline Treatments & Coverage (\%) & pH \\
\hline 1. Thiamethoxam & $37.6 \mathrm{~b}$ & 7.7 \\
\hline 2. Thiamethoxam + Break-Thru ${ }^{\circledR} S 240$ & $49.0 \mathrm{a}$ & 7.6 \\
\hline 3. Thiamethoxam + Break-Thru ${ }^{\circledR}$ S233 & $42.8 \mathrm{ab}$ & 7.6 \\
\hline 4. Thiamethoxam + Break-Thru ${ }^{\mathbb{B}}$ Union & $39.9 \mathrm{ab}$ & 7.7 \\
\hline 5. Thiamethoxam + Oil FC Agraröl ${ }^{\mathbb{B}}$ & $42.2 \mathrm{ab}$ & 7.5 \\
\hline 6. Thiamethoxam + Naturo'il ${ }^{\circledR}$ & $45.7 \mathrm{ab}$ & 7.2 \\
\hline 7. Water & - & 7.0 \\
\hline \multirow[b]{2}{*}{ Treatments } & 5.8 & - \\
\hline & Coverage (\%) & pH \\
\hline 1. Imidacloprid & $42.0 \mathrm{~b}$ & 6.7 \\
\hline 2. Imidacloprid + Break-Thru ${ }^{\circledR} S 240$ & $56.7 \mathrm{a}$ & 7.2 \\
\hline 3. Imidacloprid + Break-Thru ${ }^{\circledR} \mathrm{S} 233$ & $48.0 \mathrm{ab}$ & 6.9 \\
\hline 4. Imidacloprid + Break-Thru ${ }^{\circledR}$ Union & $42.2 \mathrm{~b}$ & 7.1 \\
\hline 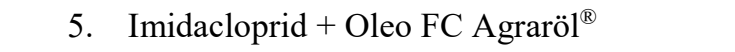 & $43.4 \mathrm{~b}$ & 7.0 \\
\hline 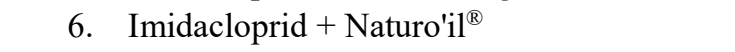 & $46.9 \mathrm{ab}$ & 6.9 \\
\hline 7. Water & - & 7.0 \\
\hline \multirow[b]{2}{*}{ Treatments } & 5.3 & - \\
\hline & Coverage (\%) & pH \\
\hline 1. Lambda-cyhalothrin & $37.9 \mathrm{~b}$ & 7.7 \\
\hline 2. Lambda-cyhalothrin + Break-Thru ${ }^{\circledR} \mathrm{S} 240$ & $50.6 \mathrm{a}$ & 7.6 \\
\hline 3. Lambda-cyhalothrin + Break-Thru ${ }^{\circledR} \mathrm{S} 233$ & $43.7 \mathrm{ab}$ & 7.6 \\
\hline 4. Lambda-cyhalothrin + Break-Thru ${ }^{\mathbb{B}}$ Union & $41.9 \mathrm{ab}$ & 7.7 \\
\hline 5. Lambda-cyhalothrin + Oleo FC Agraröl ${ }^{\circledR}$ & $42.7 \mathrm{ab}$ & 7.5 \\
\hline 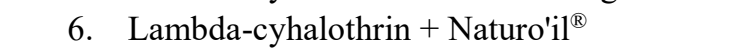 & $45.4 \mathrm{ab}$ & 7.2 \\
\hline 7. Water & - & 7.0 \\
\hline $\mathrm{CV} \%$ & 5.7 & - \\
\hline
\end{tabular}

* Values followed by the same letter in a column were not significantly different according Tukey's test at $5 \%$ probability level.

Droplet coverage showed an inverse relationship with the contact angle, i.e., the treatments with the lowest contact angle had the highest coverage. The addition of Break-Thru ${ }^{\circledR}$ S240 resulted in a coverage of $49 \%$ to $56 \%$, varying with the insecticide tested. Because coverage is related to the reduction of surface tension and contact angle, products that have this capacity can increase the coverage area and improve agricultural applications. The interference of surface tension with droplet coverage was also mentioned by Costa et al. (2017), who stated that reducing surface tension may result in increased droplet coverage.

Thus, the use of adjuvants in the spray solution can interfere with factors from the spray tank $\mathrm{pH}$ and surface tension) to the drop reaching the leaf surface (contact angle and coverage). Its use associated with herbicides and fungicides has always been a common practice in Brazilian agriculture. However, adding insecticides has proven to be a viable alternative to avoid losses, improve product coverage, and consequently increase the biological efficiency of insecticides in the field (Melo et al., 2015).

The influence of rain on spraying has been studied for several years. However, its response varies according to the active ingredient and the formulation, so each case should be evaluated separately (Hunsche et al., 2007). Moreover, the characteristic deposit formation after application is one of the factors that interferes with the efficiency of agricultural products. In this context, the use of scanning electron microscopy allows for a qualitative analysis of the deposit properties and the interaction with the plant surfaces. Scanning electron microscope images showed that there is no deposit pattern for any of the insecticides alone or in association with the adjuvants (Figures 1 and 2).

It was possible to observe the residues in most of the images, which indicates that although rainfall considerably affects the removal of these active ingredients, not all the product on the leaf is removed by the impact of the rain drops. Wheat leaves had a higher amount of residue, which may be related to their higher water repellency (more hydrophobic leaves according to the contact angle data), and their greater vertical position compared to maize leaves. Furthermore, treatments with adjuvants had a higher amount of residue, which illustrates the effect of these products. 

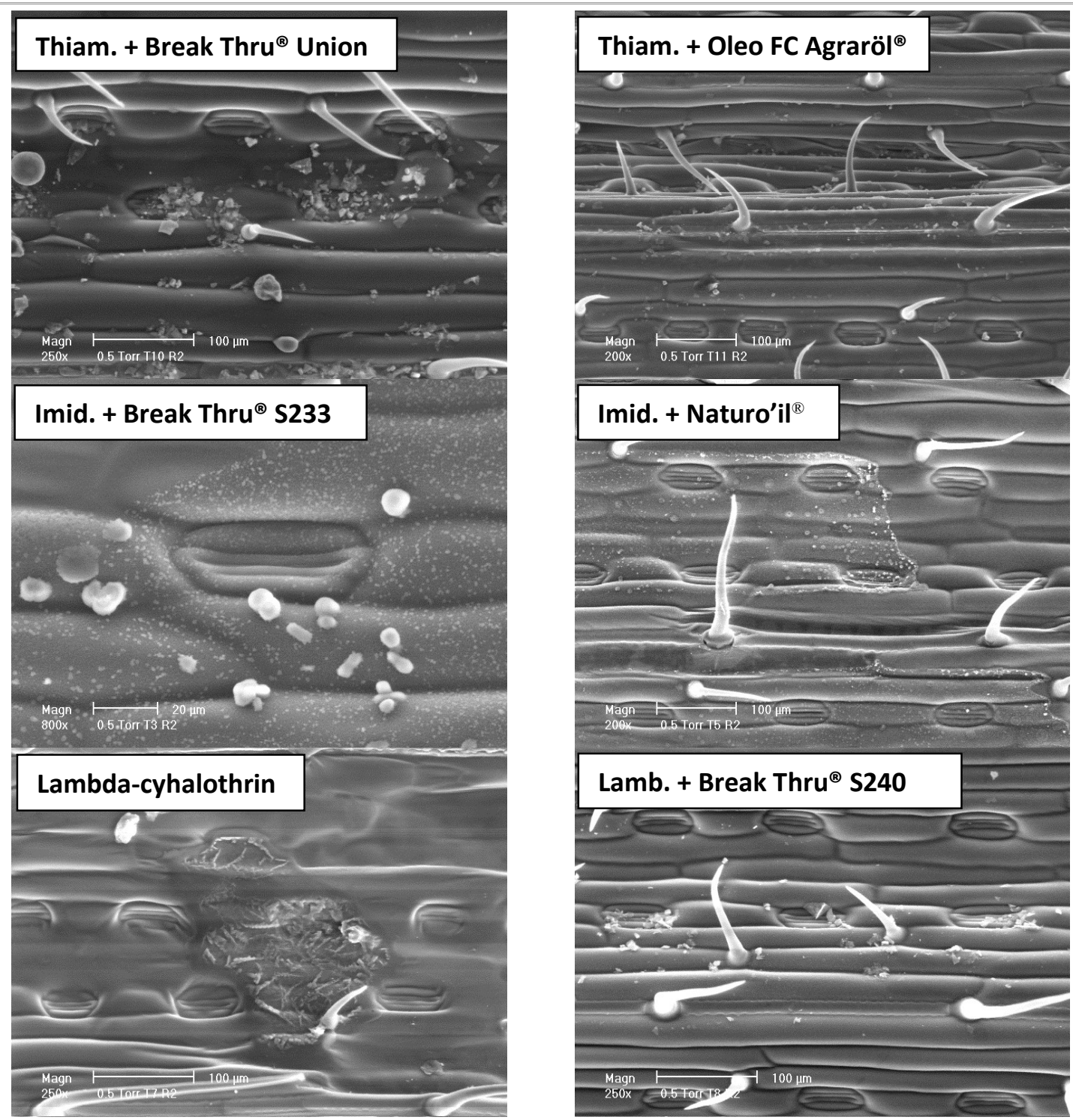

FIGURE 1. Scanning electron microscopy images of insecticide deposits associated with adjuvants after simulated rain (5 mm) on wheat leaves.

The use of adjuvants in association with insecticides can reduce surface tension and the contact angle between the leaf and droplet, increasing the coverage of drops and decreasing the deleterious effect of rain,

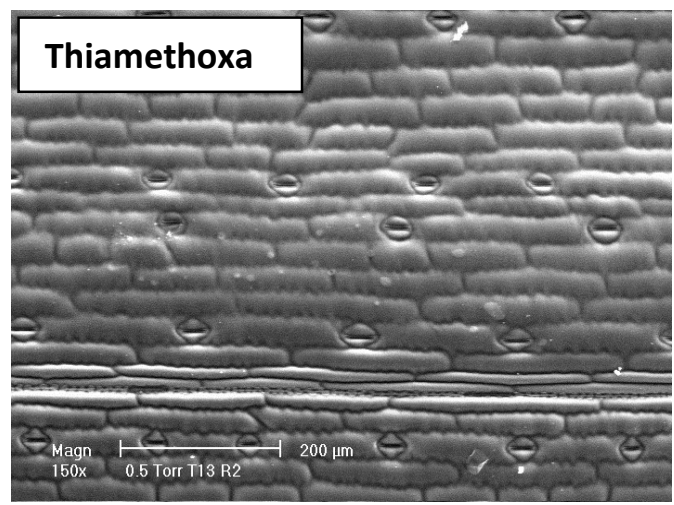

without altering the $\mathrm{pH}$ of the spray solution. Therefore, its use, considering technical criteria when choosing the adjuvant, may lead to an improvement in the biological efficiency of insecticides used in wheat and maize crops.

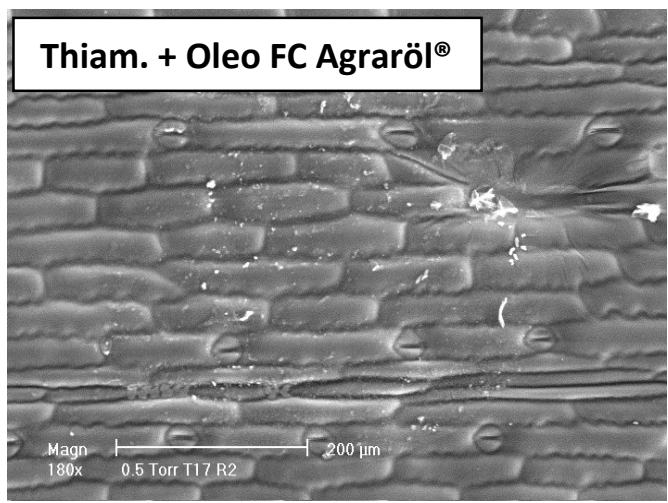



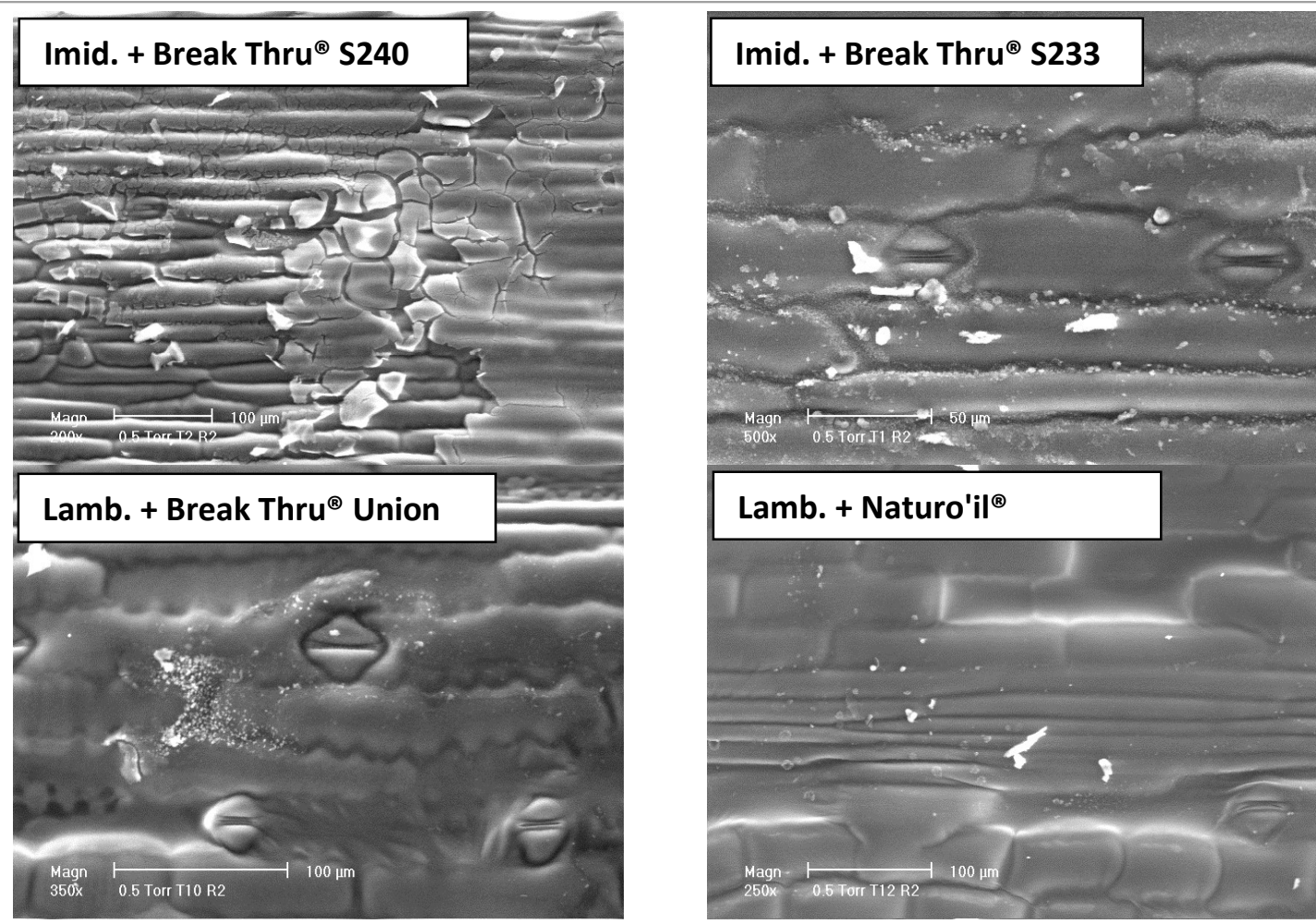

FIGURE 2. Scanning electron microscopy images of insecticide deposits associated with adjuvants after simulated rain (5 mm) on maize leaves.

\section{CONCLUSIONS}

The addition of Break-Thru ${ }^{\circledR}$ S240 and BreakThru ${ }^{\circledR}$ S233 in the thiamethoxam, imidacloprid, and lambda-cyhalothrin insecticides resulted in lower values of surface tension and contact angle in wheat and maize leaves. Moreover, the coverage of these treatments was higher than that of the others, improving the quality of the applications.

The $\mathrm{pH}$ of the spray solution did not change with the adjuvants tested. The electron microscopy images showed residues of the active ingredient even after rain. Moreover, maize leaves retain less residue than wheat leaves and the use of adjuvants results in more residue on wheat and maize leaves.

The use of adjuvants associated with insecticides can improve the physicochemical properties of spray solutions. The addition of the adjuvant can be an alternative to improve the efficiency of insecticides, allowing the product to express its full control potential.

\section{ACKNOWLEDGMENTS}

The authors thank Knut Wichterich for the technical support and CAPES for financing the development of the project.

\section{REFERENCES}

Azevedo L, Castelani P (2013) Agricultural adjuvants for crop protection. Rio de Janeiro, Imos Gráfica Editora, 236p.
Castro EB, Carbonari CA, Velini ED, Gomes GLGC, Belapart D (2018) Influence of adjuvants on the surface tension, deposition and effectiveness of herbicides on fleabane plants. Planta Daninha 36. DOI:

https://dx.doi.org/10.1590/s0100-83582018360100067

Costa LL, Silva H.JPS, Almeida DP, Pontes NC, Ferreira MC (2017) Droplet spectra and surface tension of spray solutions by biological insecticide and adjuvants.

Engenharia Agrícola 37(2):292-301. DOI: http://dx.doi.org/10.1590/1809-4430eng.agric.v37n2p292-301/2017

Cunha JPAR, Alves GS, Marques RS (2017) Tensão superficial, potencial hidrogeniônico e condutividade elétrica de caldas de produtos fitossanitários e adjuvantes. Revista Ciência Agronômica 48(2):261-270. DOI: http://dx.doi.org/10.5935/1806-6690.20170030

Hazen JL (2000) Adjuvants - terminology, classification, and chemistry. Weed Technology 14:773-784. DOI: https://doi.org/10.1614/0890037X(2000)014[0773:ATCAC]2.0.CO;2

Hess FD, Foy CL (2000) Interaction of surfactants with plant cuticles. Weed Technology 14:807-813. DOI: https://doi.org/10.1614/0890037X(2000)014[0807:IOSWPC]2.0.CO;2

Hunsche M, Damerow L, Schmitz-Eiberger M, Noga G (2007) Mancozeb wash-off from apple seedlings by simulated rainfall as affected by drying time of fungicide deposit and rain characteristics. Crop Protection 26:768774. DOI: https://doi.org/10.1016/j.cropro.2006.07.003 
Hunsche M, Alexeenko A, Damerow L, Noga G (2011)

Rain-induced removal of copper from apple leaves:

Influence of rain properties and tank-mix adjuvants on deposit characteristics at the micro scale. Crop Protection 30:495-501. DOI:

https://doi.org/10.1016/j.cropro.2010.11.028

Melo AA, Guedes JVC, Storck L, Swarowsky A, Cagliari D, Burtet LM, Arnemann JA (2014) Precipitação artificial após aplicação do inseticida clorantraniliprole associado com adjuvante em plantas de soja. Ciência Rural 44(12):2118-2123. DOI: http://dx.doi.org/10.1590/0103$8478 \mathrm{cr} 20120211$
Melo AA, Usano-Alemany J, Guedes JVC, Hunsche M (2015) Impact of tank-mix adjuvants on deposit formation, cuticular penetration and rain-induced removal of chlorantraniliprole. Crop Protection 78:253-262. DOI: http://dx.doi.org/10.1016/j.cropro.2015.09.021

Wang CJ, Liu ZQ (2007) Foliar uptake of pesticides Present status and future challenge. Pesticide Biochemistry and Physiology 87(1):1-8. DOI:

https://doi.org/10.1016/j.pestbp.2006.04.004

Yuan Y, Lee TR (2013) Contact Angle and Wetting Properties. In Surface Science Techniques. Springer nature, 663p. 